\title{
Apontamentos sobre Jurisdição Administrativa e o Conselho de Estado do Brasil-Império
}

\author{
Notes on the Administrative Justice and the Council of State of the Empire of \\ Brazil
}

\begin{abstract}
MARCIO FELIPE LACOMBE DA CUNHA
Possui Graduação em Direito pela Universidade Federal do Estado do Rio de Janeiro (UniRio), Especialização em Direito Público pela Universidade de Brasília (UnB) e cursa, atualmente, o Mestrado em Direito Constitucional da Universidade Federal Fluminense (UFF), na linha de pesquisa: Instituições Políticas, Administração Pública e Jurisdição Constitucional. É Advogado da União (AGU) e, atualmente, ocupa a função de Presidente da Junta Recursal, da Junta de Julgamento da Aeronáutica (JJAER). Foi membro do Grupo Permanente de Atuação Pró-Ativa da Procuradoria-Geral da União. Tem experiência na área do Direito Público, com ênfase no Direito Administrativo.
\end{abstract}

RESUMO: 0 que hoje se conhece por Direito Administrativo adveio da França. Os princípios que constituem a base desse ramo do direito foram construídos, sobretudo, a partir da jurisprudência do Conselho de Estado francês, órgão instituído no ano de 1799 para exercer competência consultiva e, posteriormente, também o julgamento dos litígios entre a Administração e os administrados. Instituiu-se, assim, o denominado contencioso administrativo, isto é, a separação entre duas ordens de jurisdição: a administrativa e a comum. 0 Direito Administrativo brasileiro, tal como em diversos países, sofreu forte influência do Direito francês, notadamente no tempo do Império. Nesse período, foi instituído o Conselho de Estado brasileiro, que durou até a Proclamação da República, em 1889, como órgão auxiliar do Poder Moderador, a quem cabia, ainda, pronunciar-se sobre os litígios entre a Administração e os particulares, embora em caráter meramente consultivo. 0 sistema de dualidade da jurisdição, notadamente quando estruturado em tribunais administrativos autônomos, possui algumas vantagens, entre as quais se destaca a especialização proporcionada aos Magistrados. 0 estudo do contencioso administrativo na Europa, bem como do Conselho de Estado brasileiro, é fundamental para a melhor compreensão das raízes históricas e a evolução do Direito Administrativo brasileiro.

PALAVRAS-CHAVE: Direito Administrativo; contencioso administrativo; Conselho de Estado do Brasil-Império.

ABSTRACT: What today is known as Administrative Law stemmed from France. The principles that form the basis of this branch of law were built mainly from the jurisprudence of the French Council of State, organ established in the year 1799 as legal adviser and subsequently also as an administrative court to adjudicate claims between the authorities and the citizens. Thus, was instituted the administrative justice, with separation between two types of jurisdiction: the administrative and general. The Brazilian Administrative Law, as in many other countries, was strongly influenced by French law, especially in the Empire period. During this period, was established a Council of State, which lasted until the proclamation of the Republic in 1889, as a auxiliary organ of the Moderating Power, and also 
resolving disputes between the authorities and the citizens, although in character merely advisory. The existence of two distinct orders of jurisdiction, particularly when structured into administrative courts with independence, has some advantages, among which stands out the specialization provided to the judges. The study of administrative justice in Europe and the Council of State of Brazil it is important to understand the historical roots and the evolution of the Brazilian Administrative Law.

KEYWORDS: Administrative Law; administrative justice; Council of State of Brazilian Empire.

SUMÁRIO: Introito; 1 Os sistemas de jurisdição administrativa; 2 A Constituição de 1824 e o ConseIho de Estado do Brasil-Império; Conclusão; Referências.

\section{INTROITO}

Durante o Ancien Régime, o direito público sintetizava-se no preceito segundo o qual o monarca - legislador e juiz supremo - possui o direito ilimitado de governar, proclamado nas máximas absolutistas: le roi ne peut mal faire (na versão francesa) ou the king can do no wrong (na versão inglesa). O rei, portanto, era infalível e não se submetia ao poder dos tribunais; os indivíduos, no máximo, poderiam pedir justiça contra os abusos dos representantes do soberano por meio da graça deste ou mediante recursos de caráter interno, hierárquico, os quais o monarca não tinha qualquer obrigação jurídica de resolvê-los (Alessi, 1970, p. 570).

A Revolução Francesa, inspirada pelos ideais iluministas e alimentada pela crise dos velhos regimes da Europa e seus respectivos sistemas econômicos, eclodiu acabando de vez com o regime absolutista. Se, por um lado, essa revolução é apenas uma das revoluções burguesas que delinearam o mundo moderno, por outro, impõe-se reconhecer que seu alcance e suas consequências, inclusive na América Latina, foram muito mais profundos que o das demais revoluções. Em verdade, "entre todas as revoluções contemporâneas, a Revolução Francesa foi a única ecumênica. Seus exércitos partiram para revolucionar o mundo; suas ideias de fato o revolucionaram" (Hobsbawm, 2010, p. 99).

Com efeito, o que hoje se conhece por Direito Administrativo adveio da França, "impose comme paradigme ou modèle pour les autres droits, référentiel obligatoire dans toutes les constructions du monde administratif" (Cretella Júnior, 1973, p. 90). O Direito Administrativo foi construído, sobretudo, a partir da jurisprudência de um órgão, qual seja o Conseil d'État, responsável pelo julgamento das controvérsias entre Administração e administrados naquele país. Hodiernamente, o Conselho de Estado francês permanece integrado na estrutura do Poder Executivo, a despeito de suas decisões possuírem natureza jurisdicional, isto é, de terem força de coisa julgada (Mello, 2010, p. 38-39), funcionando como conselheiro do governo na preparação de projetos de lei, elaborando pareceres sobre questões administrativas ou políticas públicas, sob requisição governamental ou por iniciativa própria, sendo, ainda, o juiz administrativo supremo daquele país. 
Nesse contexto pós-Revolução Francesa, era necessário criar um direito novo, ainda não legislado, visto que as normas jurídicas então existentes disciplinavam relações entre particulares, inaplicáveis, pois, ao vínculo que surgia entre o Poder Público e os administrados. Este vínculo, a seu turno, demandava uma disciplina específica, governada por outros princípios, que seriam qualificados como exorbitantes, na medida em que exorbitavam do direito até então conhecido, o direito comum (Mello, 2010, p. 39). Foi a partir da atividade pretoriana do Conselho de Estado - instituído pelo art. 52 da Constituição de 22 Frimário do Ano VIIII (13 de dezembro de 1799) -, como anteriormente salientado, que se desenvolveram os princípios que constituem a base do Direito Administrativo, incorporados posteriormente ao regime jurídico de inúmeros outros países (Di Pietro, 2010, p. 5).

Nessa linha, a ratio essendi da jurisdição administrativa ou contencioso administrativo não decorre de uma justificação filosófica ou de uma imposição lógico-jurídica, eis que diversos países ocidentais não o adotaram em seus ordenamentos jurídicos, notadamente os países anglo-saxões. A jurisdição administrativa surgiu na França, a partir de um conjunto de circunstâncias históricas desse país; nasce, sobretudo, de um princípio interpretado à luz da tradição. Este princípio é o da separação de poderes (Rivero, 1981, p. 157).

Na teoria dos poderes de Montesquieu ${ }^{1}{ }^{1}$, inspirada no sistema político da Inglaterra - experiência histórica que se revelara bem sucedida desde o final do século XVII -, a liberdade (o principal dos bens) depende da separação do poder de julgar do poder legislativo e do poder executivo ${ }^{2}$. Uma vez unido ao poder legislativo, "o poder sobre a vida e a liberdade dos cidadãos seria arbitrário, pois o juiz seria legislador. Se estivesse unido ao poder executivo, o juiz poderia ter a força de um opressor" (Montesquieu, 2000, p. 168).

Como recém ressaltado, o apego ao princípio da separação de poderes, na interpretação que Ihe deram os constituintes franceses pós-revolucionários ${ }^{3}$,

1 Por oportuno, vale transcrever a advertência de Arno Wehling (2009, p. 587) sobre a teoria dos poderes de Montesquieu: "Mais conhecida, entretanto, é a teoria dos poderes de Montesquieu. Depois dos estudos de Eisenmann não se pode atribuir ao autor simplesmente a definição dos três poderes, Executivo Legislativo e Judiciário e sua separação. À época os autores iluministas em geral não pregavam ainda a doutrina da soberania popular, mas faziam uso do direito natural para aperfeiçoar a tese de Bodin sobre a soberania real, já que a principal ameaça no horizonte - inclusive de Montesquieu - não era a de uma revolução popular (isto é, de todo o terceiro Estado), nem sequer burguesa, mas a da escalada do absolutismo rumo ao despotismo, quadro mais tarde caracterizado como despotismo esclarecido" (grifos do autor).

2 Segundo Hans Kelsen (p. 365), contudo, quando se fala dos três poderes do Estado, o poder deve ser compreendido como uma função do Estado. Consoante o autor, ainda, a execução das leis, isto é, das normas jurídicas gerais também é função do chamado poder judiciário, que, nesse sentido, não seria distinguível do poder executivo. Assim, a tricotomia usual consistiria, no fundo, em uma dicotomia, "a distinção fundamental entre legis latio e legis executio".

3 Ao longo da Revolução Francesa, uma série de textos legais foi editada a fim de impedir que o juiz invadisse as atribuições próprias da Administração (Rivero, p. 158). Entre estes, destaca-se, v.g., a Lei de 16-24 de agosto de 1790, cujo título II, art. 13, dispunha: "Les fonctions judiciaires sont distinctes et demeureront toujours séparées des fonctions administratives. Les juges ne pourront, à peine de forfaiture, troubler, de quelque manière que ce soit, les opérations des corps administratifs, ni citer devant eux les administrateurs pour raison de leurs fonctions". 
aliada à desconfiança em relação aos juízes do velho regime - os revolucionários temiam que os corpos judiciários retomassem, no tocante à nova administração, a tradição de ingerência e de oposição dos parlamentos (como eram chamados os tribunais de instância superior no período do Antigo Regime) à administração real (Rivero, 1981, p. 158) -, serviram, pois, para a criação, em França, da jurisdição administrativa, ao lado da jurisdição comum, instituindo-se o denominado sistema de dualidade da jurisdição (Di Pietro, 2010, p. 4).

A jurisdição administrativa desenvolve-se, sem publicidade, na França, no período de 1808 a 1818. Entretanto, a inauguração da primeira cátedra de Direito Administrativo na Universidade de Paris, em 1828, imprimiu considerável impulso a essa disciplina, o que atraiu a atenção de juristas e professores de todo o mundo (Cretella Júnior, 1966, p. 239). Naquele interregno, tem início a chamada Escola Francesa, também conhecida como Escola Legalista, Empírica, Exegética ou Caótica, segundo a qual o Direito Administrativo deve ser compreendido de maneira restrita, isto é, como sinônimo perfeito de direito positivo; nesse sentido, "estudar o direito administrativo dum país seria, então, colecionar e em seguida comentar o conjunto das leis administrativas desse país" (Cretella Júnior, 1966, p. 146).

Até o ano VIII, na França, era o próprio administrador ativo (o soberano) e, após a queda da monarquia, os ministros ou, para outras categorias de litígios, o diretório de departamento, quem decidia os conflitos nos quais houvesse interesse da Administração. É o denominado sistema do administrador-juiz que, de fato, não oferecia aos particulares qualquer segurança, "uma vez que é em causa própria que o administrador é juiz" (Rivero, 1981, p. 159). No entanto, a partir daquele ano, com a criação do Conselho de Estado junto ao poder central e o Conselho de Prefeitura junto ao prefeito - ambos com atuação meramente consultiva -, começou-se a desenvolver uma verdadeira jurisdição administrativa, esboçando-se, ademais, no seio da Administração Pública, uma nova separação entre a função ativa e a função jurisdicional, que, por sua vez, se distingue da separação de poderes. Esta diz respeito às relações entre Executivo e Judiciário, enquanto aquela diz respeito à divisão do trabalho no âmbito do próprio Executivo. Portanto, "foi desta separação de funções que nasceu a jurisdição administrativa" (Rivero, 1981, p. 159).

Deveras, o Conselho de Estado francês somente passou a exercer função jurisdicional a partir da reforma de 1872, quando "se le confirió la potestad de dictar resoluciones con eficacia de actos jurisdiccionales inmediatamente ejecutivos sin requerir, como ocurría anteriormente, la firma del Jefe del Estado" (Alessi, 1970, p. 582). É dizer: operou-se em França a transição do regime de jurisdição administrativa homologável - tradução da expressão francesa justice retenue - para o regime de jurisdição delegada (Aragão, 1955, p. 11-12). Desde 1872, existe também na França um Tribunal de Conflitos, integrado por membros do Conselho de Estado e do Tribunal de Cassação, presidido pelo Ministro da Justiça, cuja função essencial é resolver os conflitos de atribuição ou de 
competência, "que se levantam entre a ordem judicial e a ordem administrativa a propósito da competência respectiva das duas jurisdições" (Rivero, 1981, p. 166).

O Direito Administrativo brasileiro, tal como sucedeu em diversos outros países, sofreu forte influência do Direito francês, bem como de outros direitos enquadrados no sistema de base romanística (italiano, alemão, português, etc.). Sem embargo, sofreu alguma influência do sistema da commom law, notadamente do direito norte-americano (Di Pietro, 2010, p. 22). No período do Brasil-colônia não houve cultores especializados do Direito Administrativo, o qual não se afirmara ainda como uma disciplina jurídica autônoma. De fato, a acanhada literatura jurídica achava-se inserta em tratados gerais de direito público, e os textos de lei portugueses eram transplantados para o Brasil e adaptados, tanto quanto possível, às necessidades locais (Cretella Júnior, 1966, p. 168).

Contudo, pouco a pouco aumenta no país o interesse pelo Direito Administrativo. Em 1833, o Ministro do Império, Senador Nicolau Pereira de Campos Vergueiro, apresentou às Câmaras o projeto de criação de uma Cadeira de Direito Administrativo, que, no entanto, passou a existir como disciplina jurídica autônoma nas faculdades de direito brasileiras, apenas com a edição do Decreto no 608, de 16 de agosto em 1851 (Cretella Júnior, 1966, p. 169).

No tempo do Império, destaca-se a forte influência do direito francês, sobretudo ao considerar-se a instituição do Conselho de Estado brasileiro ${ }^{4}$ pela Lei no 234, de 23 de novembro de 1841, como órgão auxiliar do Poder Moderador

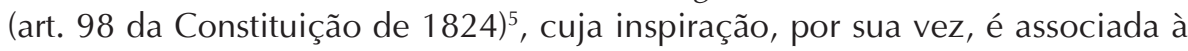
teoria liberal do pouvoir neutre, de Benjamin Constant ${ }^{6}$. Como já ressaltado, o

4 Por oportuno, vale transcrever a advertência de José Reinaldo Lima Lopes (2010, p. 113) sobre a existência de três Conselhos no período do Império, sendo que o último deles - que será esmiuçado adiante no presente trabalho - é o Conselho de Estado de que trata sua obra: "O primeiro foi o Conselho dos Procuradores das Províncias (1822-1823), o segundo foi o Conselho da Carta de 1823 (1823-1834), abolido pela reforma constitucional de 1834. 0 terceiro, sobre cuja atividade versa esta investigação, durou de 1842 a 1889 , e foi instituído pela Lei $n^{\circ} 234$, de novembro de 1841 . Este terceiro Conselho foi o que funcionou efetivamente $e$ terminou por constituir a jurisprudência a ser examinada no capítulo seguinte".

5 "Art. 98. o Poder Moderador é a chave de toda a organisação Politica, e é delegado privativamente ao Imperador, como Chefe Supremo da Nação, e seu Primeiro Representante, para que incessantemente vele sobre a manutenção da Independencia, equilibrio, e harmonia dos mais Poderes Politicos".

6 Segundo Carl Schmitt, em sua obra O Guardião da Constituição (2007, p. 194-195), a influência da teoria do pouvoir neutre, intermédiaire e régulateur, que desponta com Benjamin Constant na luta da burguesia francesa por uma Constituição liberal contra a o bonapartismo e a restauração monárquica, fez-se presente no catálogo de prerrogativas e poderes do chefe de Estado (monarca ou presidente), típico para todas as Constituições do século XIX. Neste particular, Schmitt chega a fazer expressa menção (em nota de rodapé) à Constituição brasileira de 1824, que teria adotado a teoria do pouvoir neutre de forma bastante literal (art. 98). É interessante registrar, ainda, o fato de que Schmitt utiliza-se dessa teoria, surgida, como é de sabença geral, em outro contexto histórico-político, com vistas à defesa de uma monarquia constitucional em França, para justificar a posição do presidente do Reich como guardião da Constituição, pois, segundo ele, o "peculiar equilíbrio, frequentemente discutido, do elemento constitucional plebiscitário com o parlamentar, a relação de uma independência do parlamento do Reich devido aos poderes autônomos com uma dependência devido à exigência geral da referenda ministerial (art. 50 da Constituição do Reich), a execução pelo Reich, i.e. proteção da Constituição do Reich perante os Estados e, por fim, a proteção da Constituição (diferentemente da norma constitucional em particular) conforme o art. 48 da Constituição do Reich, tudo isso seria uma 
Conselho de Estado francês, na sua fase inicial, tal como o Conselho de Estado brasileiro, também não detinha independência, sendo suas manifestações - de natureza consultiva - submetidas à aprovação do rei (Di Pietro, 2010, p. 22).

Por fim, com a proclamação da República, em 1889, suprime-se o Poder Moderador e o seu auxiliar, o Conselho de Estado, abandonando-se no Brasil, de vez, o sistema de dualidade da jurisdição de influência francesa. Ato contínuo, acolhe-se o modelo anglo-americano da unidade dos órgãos jurisdicionais - mantido em todas as Constituições republicanas que se seguiram. Desse modo, a Administração Pública brasileira foi submetida ao controle jurisdicional; a jurisprudência, sob influência do direito norte-americano, passou a ocupar lugar de destaque como fonte do direito (Di Pietro, 2010, p. 22-23).

\section{OS SISTEMAS DE JURISDIÇÃO ADMINISTRATIVA}

Consoante Themistocles Brandão Cavalcanti (1945, p. 495-496), o sistema de controle dos atos praticados pela Administração Pública em relação a terceiros, partes nas relações jurídicas que deles decorrem, ou dos litígios administrativos de um modo geral, pode ser subdividido em três tipos fundamentais, a saber: 1ํ) o sistema do administrador-juiz, isto é, da integração dos órgãos da jurisdição administrativa na estrutura da própria Administração; 2o) o sistema dos tribunais administrativos autônomos; e $3^{\circ}$ ) o sistema judiciarista ou da unidade dos órgãos jurisdicionais.

No primeiro sistema, apresentam-se múltiplas variedades, desde o julgamento pelo próprio agente, ou seja, pela autoridade que praticou o ato administrativo questionado, passando pela chamada revisão hierárquica, até o julgamento por órgãos especiais que, a seu turno, podem ser constituídos por agentes da própria Administração Pública ou estruturados como órgãos consultivos, sem que seus membros possuam função materialmente administrativa (Moreira Neto, 1977, p. 10). Historicamente, o sistema do administrador-juiz apresenta-se "comme un stade initial précédant et préparant l'apparition d'une jurisdiction administrative autonome; on va voir que c'est ce processus de transformation qui s'est réalisé précisément en France" (Cretella Júnior, 1973, p. 219).

No segundo sistema, defere-se o contencioso administrativo, por cláusula geral, a tribunais administrativos autônomos (sistema de dualidade da jurisdição) que, por exercerem função jurisdicional, ficariam mais bem situados na estrutura do Poder Judiciário; contudo, nada obsta que, como ocorre em diversos países, se alinhem topologicamente no âmbito do Poder Executivo (Moreira Neto, 1977, p. 10). Neste sistema, enquadrar-se-iam, ainda, as denominadas comissões administrativas, com funções quase judiciais, em vigor nos Estados Unidos da América e, de alguma forma, na Inglaterra (Cavalcanti, 1945, p. 497).

mistura contraditória e absurda de determinações incompatíveis, se não se tornasse compreensível por intermédio dessa teoria" (Schmitt, 2007, p. 201). 
Entretanto, é importante salientar que, no sistema norte-americano, os tribunais administrativos (Courts, Boards e Comissions) não proferem decisões com força de coisa julgada (final enforcing power), sempre cabendo ao Judiciário revê-las, nas matérias de fato e de direito (Moreira Neto, 1977, p. 15).

No terceiro sistema, da unidade dos órgãos jurisdicionais (modelo anglo-americano), compete ao Poder Judiciário resolver os litígios envolvendo a Administração Pública e os administrados, segundo o princípio una lex, una jurisdictio (Cretella Júnior, 1973, p. 230). Deste sistema derivam duas subsoluções, quais sejam um sistema de competência exclusiva e um sistema de competência parcial. Este último, por sua vez, consiste na partilha de competência ou entre a jurisdição ordinária e a Administração Pública, ou entre a jurisdição ordinária e a jurisdição administrativa ou entre as três (Moreira Neto, 1977, p. 10).

Em termos de direito comparado, não há como se falar em sistemas de justiça administrativa absolutamente puros (Moreira Neto, 1977, p. 12). Não obstante, como visto anteriormente, costuma-se colocar em polos opostos, de um lado, os Estados Unidos da América e Inglaterra, nos quais há predominantemente competência dos tribunais ordinários e, de outro, a França, em que há duas ordens de jurisdição: a administrativa e a judicial. Na América Latina, de acordo com José Cretella Júnior (1973, p. 230-231), também não se observam soluções uniformes, eis que alguns países (v.g. Panamá, Equador, Colômbia) recorreram à solução francesa, com poucas modificações, reconhecendo a dualidade de jurisdição e atribuindo aos seus respectivos Conselhos de Estado autonomia para o contencioso administrativo.

Sem embargo, a opção pelo sistema judiciarista ou da unidade dos órgãos jurisdicionais está presente em muitas repúblicas da América Latina, inclusive no Brasil, por conta da inegável influência dos Estados Unidos da América, de sua estrutura federal, conforme lição de José Cretella Júnior, que destaca, ainda, as criações originárias do juicio de amparo 7 e do mandado de segurança, provenientes, respectivamente, do Direito mexicano e do Direito brasileiro, como instrumentos de proteção dos cidadãos contra os atos administrativos ilegais, veja-se:

L'option pour le système judicialiste se trouve en grand nombre d'États latino-américains, et on y remarque incontestable I'influence des États Unis de l'Amérique du Nord, de strucure fédérale.

7 Assim dispõe o art. 107, I, da Constituição Política dos Estados Unidos Mexicanos:

"Artículo 107. Las controversias de que habla el artículo 103 de esta Constitución, con excepción de aquellas en materia electoral, se sujetarán a los procedimientos que determine la ley reglamentaria, de acuerdo con las bases siguientes:

I. El juicio de amparo se seguirá siempre a instancia de parte agraviada, teniendo tal carácter quien aduce ser titular de un derecho o de un interés legítimo individual o colectivo, siempre que alegue que el acto reclamado viola los derechos reconocidos por esta Constitución y con ello se afecte su esfera jurídica, ya sea de manera directa o en virtud de su especial situación frente al orden jurídico" (grifos nossos). 
D'un autre côté, l'idéologie libéraliste continentale influe sur le système du contrôle de la constitucionnalité des lois et sur le controle formel des actes administratifs, rehaussant le principe de la séparation des Pouvoirs, au bénéfice de l'autorité judiciaire.

Dans un groupe important d'États sud-américains (Brésil, Mexico, Chili et Pérou), les juges ordinaires exercent le contrôle de la légalité des actes administratifs.

Le 'juicio de amparo' (jugement de protection) du droit méxicain et le 'mandado de segurança' (mandat, ordre de sécurité) du droit brésilien sont des créations juridiques originales que le citoyen peut soulever devant le juge lorsqu'un acte administratif quelconque, réglementaire ou individuel, a enfreint la légalité. Les deux recours sont des procès faits à des actes qui doivent être annulés. (1977, p. 231-232)

Durante o período do Império no Brasil, observa-se que os atos praticados pelo Poder Executivo e, evidentemente, pelo Poder Moderador, não se submetiam ao controle jurisdicional, isto é, vigorava o sistema do contencioso administrativo de influência francesa que, na observação do Visconde do Uruguay (1862, p. 157), e excluindo-se o que diz respeito ao Ministro da Fazenda, do Tesouro e das repartições que lhes são sujeitas, era "um verdadeiro cháos, no qual ainda não penetrou um só raio de luz". Havia, portanto, uma divisão de competências entre as matérias de competência da autoridade judiciária, relacionadas às coisas privadas, e aquelas relacionadas à autoridade administrativa, referentes às relações entre as coisas públicas e as particulares (Di Pietro, 2002, p. 11).

As funções do Conselho de Estado brasileiro eram meramente consultivas, consoante anteriormente ressaltado. E, mesmo quando apreciava questões contenciosas, suas manifestações ficavam sujeitas à aprovação do Imperador. Neste sentido, o Conselho de Estado brasileiro não exercia função jurisdicional propriamente dita, como exerce hoje o Conselho de Estado na França e em outros países, que adotaram semelhante modelo. Registre-se, mais uma vez, que dos seus primórdios até a reforma de 1872, as decisões do Conseil d'État também dependiam do aval do Rei, correspondendo ao período da chamada justiça retida (Di Pietro, 2002, p. 9).

Com a Constituição republicana de 1891 - que sofreu influência do federalismo norte-americano ${ }^{8}$-, suprime-se o Poder Moderador e o seu auxiliar, o Conselho de Estado, abandonando-se a influência francesa da dualidade de jurisdição e, doravante, acolhendo-se o modelo anglo-americano da unidade

8 Por oportuno, vale transcrever a crítica do jurista e historiador gaúcho Alfredo Varela à Constituição de 1891, no que concerne à tentativa desta de reproduzir condições político-sociais de outros países: "Os constituintes de 1891 seguiram em tudo o mesmo irracional procedimento de seus antecessores imperiaes. Para elles a nacionalidade brasileira continuava a ser cousa análoga a esse barro de que se servem os estatuarios, muito susceptível de receber a fôrma que a imaginativa lhes suggerisse: tomaram do modelo norte-americano, imitaram-Ihe os contornos, e eis ahi como surgiu de ponto em branco a Constituição de 24 de fevereiro" (Varela, 1902, p. 26, grifos nossos). 
de jurisdição (Di Pietro, 2002, p. 14). Inseriu-se, ainda, no corpo do Decreto no 848 , de 11 de outubro de 1890 (que organizava a Justiça Federal), o emblemático dispositivo do art. 387, segundo o qual constituía legislação subsidiária da jurisprudência e do processo federal, além das antigas leis do processo criminal, civil e comercial, os estatutos dos povos cultos e especialmente os que regem as relações jurídicas na República dos Estados Unidos da América do Norte, os casos de common law e equity.

Entretanto, o controle judicial dos atos administrativos iniciou-se, de fato, como um instituto autônomo, com a edição da Lei no 221, de 20 de novembro de 1894, que institui uma ação específica para a anulação de tais atos, autorizando o juiz ordinário a anular, total ou parcialmente, ato ou decisão ilegal emanados das autoridades administrativas, restringindo-se o alcance desse controle, porém, quanto à conveniência e quanto à oportunidade da ação do agente público, o que hoje se denomina de mérito administrativo (Moreira Neto, 1977, p. 18).

No Brasil, portanto, desde a Constituição de 1891 vigora o sistema de unidade de jurisdição e à submissão da Administração Pública ao Poder Judiciário, ainda que as teorias e princípios do direito francês, criados pela jurisdição administrativa, permanecessem influindo sobre a doutrina e jurisprudência pátrias, "derrogando o direito privado antes aplicado à Administração e criando regime jurídico próprio que acabou por dar autonomia ao direito administrativo" (Di Pietro, 2002, p. 15). A Reforma do Judiciário, introduzida pela Emenda Constitucional no 7, de 13 abril de 1977, cujo objetivo prioritário era desafogar a Justiça Federal que, já em 1975, apresentava a expressiva soma de 318.000 processos em primeira instância e 7.000 na segunda (Moreira Neto, 1977, p. 71), buscou reintroduzir uma espécie de contencioso administrativo no Brasil ${ }^{9}$ - que acabou não sendo regulamentado pelas leis exigidas pelo texto daquela Emenda Constitucional - para questões fiscais e previdenciárias, por exemplo. No entanto, não foi conferida às suas decisões o atributo da definitividade, "nem se o compatibilizou estritamente com o sistema de jurisdição una, tornando peça formal do Poder Judiciário" (Moreira Neto, 1977, p. 72).

A Constituição de 1988, por sua vez, consagrou o princípio da inafastabilidade do controle jurisdicional, expresso em seu art. 5ㅇ, XXXV, segundo o

9 "Art. 111. A lei poderá criar contencioso administrativo e atribuir-lhe competência para o julgamento das causas mencionadas no artigo anterior (Art. $153, \S 4^{\circ}$ ).

[...]

Art. 203. Poderão ser criados contenciosos administrativos, federais e estaduais, sem poder jurisdicional, para a decisão de questões fiscais e previdenciárias, inclusive relativas a acidentes do trabalho (Art. $153, \S 4^{\circ}$ ).

Art. 204. A lei poderá permitir que a parte vencida na instância administrativa (Arts. 111 e 203) requeira diretamente ao Tribunal competente a revisão da decisão nela proferida.

Art. 205. As questões entre a União, os Estados, o Distrito Federal, os Municípios e respectivas autarquias, empresas públicas e sociedades de economia mista, ou entre umas e outras, serão decididas pela autoridade administrativa, na forma da lei, ressalvado ao acionista procedimento anulatório dessa decisão." 
qual "a lei não excluirá da apreciação do Poder Judiciário lesão ou ameaça a direito"; com isso, entende-se que o cidadão não está obrigado a exaurir previamente a instância administrativa para, em seguida, utilizar-se da via judiciária. Referido princípio ganha especial relevo na moderna doutrina processual ao revestir-se da "conotação de síntese da garantia constitucional de acesso à justiça" (Cintra et al., 2009, p. 55).

Por fim, cumpre trazer à baila o escólio de Jean Rivero acerca das razões que justificam, hodiernamente, a manutenção do sistema de dualidade de jurisdição, notadamente em França, sistema este que sobreviveu apesar do desaparecimento das próprias razões que justificaram sua criação, sobretudo o receio dos revolucionários de 1789 acerca das intromissões do juiz ordinário na Administração Pública. Consoante o jurista francês, a jurisdição administrativa não sobreviveu apenas por força de uma tradição; características peculiares do Direito Administrativo permitem refletir que "os juízes da Administração sabem até onde podem ir no controle que lhe impõem; e vão tanto mais longe quando estão seguros de não irem longe de mais" (Rivero, 1981, p. 162), ao passo que os magistrados ordinários, menos informados e especializados, correm o risco de serem mais reservados, excessivamente zelosos ou demasiadamente severos $10^{10}$, fazendo da Administração verdadeira adversária. Ou seja: à sua justificativa primitiva, de nítido caráter político, substitui-se uma justificativa de caráter técnico, calcada na "ideia da divisão de trabalho entre as duas ordens de jurisdições, especializadas na aplicação de dois direitos diferentes" (Rivero, 1981, p. 162).

De outro lado, Diogo de Figueiredo Moreira Neto chama a atenção para as vantagens ${ }^{11}$ da instituição de um sistema de tribunais administrativos especializados, organicamente estruturados no seio do Poder Judiciário, tendo o Supremo Tribunal Federal como cúpula extraordinária e Tribunal Constitucional - tal como previsto na atualidade -, sistema este que concorreria "para a eficiência não só da justiça, no setor específico, como de toda a Administração Pública" (Moreira Neto, 1977, p. 68), reforçando o Poder Judiciário na coparticipação nos encargos do Estado Contemporâneo. Instituindo-se os tribunais administrativos com base nesse arquétipo, garantir-se-ia "a alta unidade da interpretação do Direito e da guarda constitucional, sem sacrifício da alta qualidade da aplicação de seus ramos específicos" (Moreira Neto, 1977, p. 69).

10 Por outro lado, segundo Rivero (1981, p, 161), o sistema de dualidade de jurisdição também apresenta seus inconvenientes, pois muitas vezes é difícil saber se uma questão deve ser levada perante os tribunais administrativos ou perante os tribunais ordinários, o que causa transtornos e atrasos aos cidadãos que buscam tutela jurisdicional.

11 Segundo o magistério de William A. Robson, citado por Diogo de Figueiredo Moreira Neto (1977, p. 50-51), a justiça administrativa especializada possui, sinteticamente, as seguintes vantagens: i) é incomparavelmente mais barata que a justiça ordinária, afirmação esta confirmada a partir da observação da experiência dos Estados Unidos da América e da Inglaterra; ii) é mais célere que a justiça ordinária, por conta da simplificação do procedimento em atendimento ao princípio da oficialidade; iii) é mais eficiente, em razão do aprofundamento teórico e prático ensejado à magistratura; e iv) tem condições de coparticipar na prossecução do bem comum, coadjuvando a Administração Pública para o perfeito atendimento de suas finalidades. 


\section{A CONSTITUIÇÃO DE 1824 E O CONSELHO DE ESTADO DO BRASIL-IMPÉRIO}

Nos dois primeiros anos após a Independência do Brasil, o debate político concentrou-se na questão relativa à aprovação de uma Constituição. A Constituinte começou a reunir-se no Rio de Janeiro em maio de 1823. Logo na fala de abertura dos trabalhos uma afirmativa de D. Pedro I - que, em verdade, era cópia da existente na Carta francesa de 1814, por meio da qual o rei Luís XVIII tentara retomar a tradição monárquica, após a derrota de Napoleão - causou estranheza; o imperador jurava defender a futura Constituição "se fosse digna do Brasil e dele próprio", isto é, o "condicional deixava em suas mãos a última palavra" (Fausto, 2012, p. 127).

Ab initio, surgiram desavenças entre a Assembleia - cuja maioria de seus integrantes adotava uma postura liberal moderada, em defesa de uma monarquia constitucional que garantisse os direitos individuais e da limitação do poder do monarca - e D. Pedro I, sobretudo em torno das atribuições do Poder Executivo (no caso, do poder do imperador) e do Legislativo (Fausto, 2012, p. 127). Os constituintes desejavam que o imperador não tivesse poderes para dissolver a futura Câmara dos Deputados, forçando, quando julgasse necessário, novas eleições. A raiz do problema, entretanto, na visão de Afonso Arinos de Melo Franco (1957, p. 238), encontrava-se na reivindicação da Assembleia Constituinte de, em primeiro lugar, funcionar como legislatura ordinária e, em segundo lugar, de negar a D. Pedro I, no afã de defender sua soberania, o direito de sancionar ou vetar as leis ordinárias que ela elaborasse. Este excesso, segundo o autor, não teria sido prudente, visto que o direito de veto suspensivo do imperador fora reconhecido pela própria proposta de Constituição em discussão. Ademais, no sentir do autor, era absurdo que a Assembleia "quisesse servir de legislatura ordinária com prerrogativas especiais de exclusividade que só lhe cabiam na qualidade de Constituinte" (Franco, 1957, p. 238-239).

Por sua vez, o imperador e seus correligionários nada fizeram para alcançar uma solução transacional para o impasse; ao revés, mal cercado de conseIheiros, levado por seus impulsos e sentimentos muitas vezes contraditórios e, sobretudo, cedendo às pressões do elemento português que ainda permanecia em comandos militares, D. Pedro I foi permitindo o agravamento do conflito que mantinha a pequena cidade do Rio de Janeiro em estado de excitação permanente (Franco, 1957, p. 239).

Este conjunto de fatores levou o imperador a dissolver manu militari a Assembleia, no dia 12 de novembro de 1823, oportunidade em que foram presos vários deputados, inclusive os três Andradas. Em seguida, elaborou-se uma proposta de Constituição, tarefa para a qual o imperador incumbira o recém instituído Conselho de Estado, formado por políticos e juristas renomados do Império, entre os quais se incluía Carneiro de Campos, principal redator da futura Carta de 1824 (Franco, 1957, p. 240). A proposta foi, então, aprovada por quase todas as Câmaras Municipais, resultando na Constituição promulgada em 
25 de março de 1824, que, diga-se de passagem, não diferia muito da proposta anterior à dissolução da Assembleia (Fausto, 2012, p. 128). Contudo, não há como negar que "a história constitucional brasileira se inicia sob o símbolo da outorga" (Barroso, 2001, p. 9).

A Constituição de 1824, que vigorou sem alterações de monta até o fim do Império em 1889, a não ser pelo Ato Adicional de 1834 e pela respectiva Lei de Interpretação, fundava-se em certo compromisso liberal, a despeito de jamais ter sido considerada pelo imperador como fonte de sua legitimidade (Barroso, 2001, p. 9). A Carta de 1824, em determinados pontos, representava um avanço para a época, ao organizar os poderes, definir atribuições, garantir direitos individuais; entretanto, é bom que se diga, sua aplicação seria muito relativa, pois aos "direitos sobrepunha a realidade de um país onde mesmo a população livre dependia dos grandes proprietários rurais" (Fausto, 2012, p. 128).

De fato, tanto nos termos do projeto de Constituição, que fora apresentado à deliberação da Assembleia a $1^{\circ}$ de setembro de 1823 , quanto no texto que restou outorgado, a Constituição era do tipo semirrígida, vale dizer, os preceitos atinentes aos limites e às atribuições dos poderes, bem como aos direitos individuais só poderiam ser emendados mediante um especial e complicado processo de elaboração legislativa ${ }^{12}$; do contrário, todos os demais preceitos poderiam ser alterados pela legislação ordinária, sem as formalidades prescritas (Franco, 1957, p. 237). Por outro lado, o art. $2^{\circ}$ da Constituição de 1824 estabeleceu que o território ficava "dividido em Provincias na fórma em que actualmente se acha, as quaes poderão ser subdivididas, como pedir o bem do Estado". Neste sentido, segundo Afonso Arinos de Melo Franco, a Carta Política de 1824 preparou terreno para a instalação de uma monarquia federativa; contudo, foi "pena que os estadistas imperiais não houvessem compreendido a tempo a conveniência da marcha do Brasil para o regime federal" (Franco, 1957, p. 243), que seria uma imposição da nossa formação histórica e da nossa geografia.

Demais disso, pela Constituição de 1824, o governo brasileiro era monárquico, hereditário, constitucional e representativo (art. 3ํ). Paralelamente, a Constituição imperial estabeleceu uma divisão de poderes e dedicou-se, em seu título V, a regulamentar o denominado Poder Moderador, que, consoante os termos de seu art. 98, "é a chave de toda a organização política" e "delegado privativamente ao Imperador, como Chefe Supremo da Nação", para que "incessantemente vele sobre a manutenção da independência, equilíbrio e harmonia dos mais Poderes Políticos". Decerto, ainda, que durante o Império apenas a questão do federalismo seria mais discutida entre os juristas e políticos do que aquele referente à natureza, limites e competência do Poder Moderador, versão desfigurada da doutrina de Benjamin Constant (Cerqueira, 2006, p. 400).

12 “Art. 178. É só Constitucional o que diz respeito aos limites, e attribuições respectivas dos Poderes Politicos, e aos Direitos Politicos, e individuaes dos Cidadãos. Tudo, o que não é Constitucional, póde ser alterado sem as formalidades referidas, pelas Legislaturas ordinárias." 
Com efeito, o Poder Moderador é uma ideia de Clermont Tonnerre, consolidada e vulgarizada pelo escritor e publicista Benjamin Constant, na obra Principes de politique, que, por sua vez, se achava muito difundida no Brasil por ocasião da Assembleia Constituinte (Franco, 1957, p. 244). Houve dúvida à época sobre quem teria sugerido à inclusão, na Constituição de 1824, do Poder Moderador como "chave de toda a organização Política", expressão esta que era uma tradução do texto do próprio Benjamin Constant. Contudo, consoante Afonso Arinos de Melo Franco, após pesquisas historiográficas de Otávio Tarquínio de Sousa, autor de biografia sobre D. Pedro I, parece irrecusável o fato de que foi o próprio imperador quem fez inserir no Texto Constitucional outorgado aquela prerrogativa - inexistente, por sinal, no projeto de Constituição de 1823 -, que consolidava o seu poder pessoal, face aos três poderes políticos restantes (Franco, 1957, p. 244-245) ${ }^{13}$.

De fato, a intenção de Constant era introduzir, no governo monárquico constitucional, um princípio conservador que conferisse estabilidade política à França, capaz de estabelecer um equilíbrio entre o espírito de movimento e de conservação com os quais se deparam todas as sociedades, por meio de um órgão que, no governo parlamentar, pudesse desempenhar papel correspondente àquele que se investira, graças ao gênio de alguns de seus juízes, a Suprema Corte nos Estados Unidos da América (Franco, 1957, p. 244-245). Entretanto, consoante à observação de Marcello Cerqueira (2006, p. 403), na Carta francesa de 1814 - que serviu de base à teoria de Constant -, os ministros eram politicamente responsáveis perante o Parlamento. Aqui, por outro lado, a Constituição de 1824 não admitia responsabilidade política dos ministros em face do Poder Moderador.

Neste sentido, "a polêmica em torno dessa questão, que atravessaria a vida política do Império, careceu de sentido" (Cerqueira, 2006, p. 403). O Poder Moderador, adotado pioneiramente no Brasil e posteriormente copiado na Carta que D. Pedro I iria também outorgar a Portugal, em 1826, "não trouxe qualquer contribuição à ideia ou à prática do constitucionalismo liberal" (Cerqueira, 2006, p. 403). Portanto, quando D. Pedro I introduziu, no dizer de Paulo Bonavides, a repartição tetradimensional de poderes na Carta Política de 1824 , isto é, "trocou o modelo de Montesquieu pelo de Benjamin Constant"

13 Nesse diapasão, é a observação do Visconde do Uruguay: "Benjamin Constant não fez mais do que desenvolver a idéa, e separar, debaixo do nome de um Poder distincto, varias attribuições, que não pertencendo, nem devendo, por sua natureza e fim, pertencer ao Executivo, tinhão estado até então mais ou menos envolvidas n'elle; mistura que já muitos publicistas tinhão notado.

[...]

Quem o mostrou porém, quem o delineou, quem o creou realmente, e assim o proclamou o Senador Alves Branco no Senado, foi o Sr. D. Pedro I, primeiramente no art. 98 da nossa Constituição, depois no art. 71 da Carta Constitucional da Monarchia Portugueza.

São as unicas Constituições que conheço, que consagrão um quarto poder, no qual reunem todas as attribuições marcadas no art. 101 da Constituição, em outros paizes envolvidas no Executivo" (1862, p. 38, grifos nossos). 
(Bonavides, 2010, p. 363), o fez, segundo Afonso Arinos de Melo Franco, provavelmente, "mais no intuito de alargar o seu poder pessoal do que no de estabelecer um equilíbrio neutro entre os demais poderes" (Franco, 1957, p. 246).

Refoge ao escopo do presente trabalho, contudo, analisar a questão da reforma constitucional perpetrada pelo do Ato Adicional, sancionado a 12 de agosto de 1834, bem como a subsequente reação consubstanciada na Lei de Interpretação (Lei no 105, de 12 de maio de 1840) e, por fim, o denominado golpe da maioridade que dá início ao período parlamentarista - de origem costumeira - do segundo reinado, período este de relativa estabilidade político-constitucional14, a despeito da sucessão de 36 gabinetes (Barroso, 2001, p. 10). Passa-se a analisar, adiante, ainda que sinteticamente, o Conselho de Estado do Brasil-Império; não aquele que fora instituído por D. Pedro I, em meados de novembro de 1823, com a missão de elaborar um projeto de Constituição, sendo efetivamente contemplado na Constituição de 1824, e que restou abolido pelo Ato Adicional de 1834, mas sim aquele instituído pela Lei $n^{\circ} 234$, de 23 de novembro de 1841, e que durou de 1842, a partir de sua organização pelo Regulamento no124, até a Proclamação da República, em 1889.

O Conselho de Estado, no regime de dualidade de jurisdição que vigorou durante o período do Império, funcionava principalmente como um órgão de consulta do Poder Moderador, especialmente quanto aos assuntos mencionados nos parágrafos do art. $7^{\circ}$ da Lei $n^{\circ} 234$, de $1841^{15}$, exercendo atribuições de orientação governamental e administrativa (Aragão, 1955, p. 5). Funcionava, ainda, como instituição competente para se pronunciar sobre os conflitos de atribuição entre as autoridades administrativas e de jurisdição entre estas e o Judiciário, bem como sobre os litígios entre a Administração e os particulares, cabendo-lhe, como última instância, decidir sobre os recursos que lhe eram in-

14 Com relação aos embates políticos do oitocentos no Brasil, sobretudo no Segundo Reinado, vale conferir os famosos panfletos O Libelo do Povo, de Francisco de Sales Torres Homem, publicado em 1840 pelo futuro Visconde de Inhomirim sob o pseudônimo de Timandro; Ação; Reação; Transação, do jornalista Justiniano José da Rocha, publicado em 1855, e A Conferência dos Divinos, de Antônio Ferreira Vianna, publicado anonimamente em 1867, que foram reunidos em um único volume sob o título Três panfletários do segundo reinado, com a apresentação do historiador R. Magalhães Júnior. Em seu texto de índole panfletária, estruturado na dialética hegeliana, o conservador Justiniano José da Rocha narra, em uma linha evolutiva, as lutas políticas do período, notadamente entre os elementos: monárquico (centralizador) e democrático (federalista), consubstanciada na rivalidade entre os Partidos Conservador e Liberal, respectivamente, período este que vai da Independência, em 1822, até a chamada transação, que tem início em 1852.

15 "Art. $7^{0}$ Incumbe ao Conselho de Estado consultar em todos os negocios, em que o imperador houver por bem ouvi-lo, para resolvê-los; e principalmente:

$1^{\circ} \mathrm{Em}$ todas as occasiões, em que o Imperador se propuzer exercer qualquer das attribuições do Poder Moderador, indicadas no artigo cento e um da Constituição.

$2^{\circ}$ Sobre declaração de guerra, ajustes de paz, e negociações com as Nações estrangeiras.

$3^{\circ}$ Sobre questões de presas, e indemnisações.

$4^{\circ}$ Sobre conflictos de jurisdicção entre as Autoridades Administrativas, e entre estas, e as Judiciarias.

$5^{\circ}$ Sobre abusos das Autoridades Ecclesiasticas.

$6^{\circ}$ Sobre decretos, regulamentos, e instrucções para a boa execução das leis, e sobre propostas, que o Poder Executivo tenha de apresentar á Assembléa Geral". 
terpostos contra as decisões proferidas pelas seguintes autoridades administrativas, a saber: Ministros de Estado, Presidentes de Província e autoridades fiscais, assim como os recursos interpostos contra decisões de jurisdições especiais, como as do Tribunal do Tesouro, dos Tribunais de Comércio (na parte administrativa) e das Tesourarias Provinciais, exercendo, finalmente, "um contrôle jurisdicional sôbre os atos das autoridades eclesiásticas, origem legal da famosa questão religiosa de 1872 e 1875" (Aragão, 1955, p. 5).

Consoante José Reinaldo de Lima Lopes, é possível traçar um paralelo entre o Conselho de Estado do Brasil-Império e a Suprema Corte norte-americana. O constitucionalismo oitocentista, de um modo geral, defendia a constituição de um órgão capaz de opor-se às maiorias episódicas do Legislativo eleito. Neste sentido, o Conselho de Estado brasileiro, a despeito da precariedade de sua organização, atendia a esse objetivo "moderador e claramente conservador, sem, no entanto, anular a representatividade eleitoral" (Lopes, 2010, p. 142), da mesma forma que a Suprema Corte, ao exercer sua jurisdição originária ( $v . g$. decidindo os conflitos federativos) e sua jurisdição recursal (interpretando, em última instância, a Constituição norte-americana de 1787), terminou sendo nos Estados Unidos da América uma espécie de poder neutro ou um árbitro jurídico-político (Lopes, 2010, p. 142).

As semelhanças entre o Conselho de Estado do Brasil-Império e a Suprema Corte norte-americana - como o fato de seus membros serem indicados pro vita - não podem, contudo, levar à identificação (Lopes, 2010, p. 143). Em primeiro lugar, destaca-se o fato de os conselheiros poderem servir, simultaneamente, em outro poder, no Legislativo, e poderem se afastar, sem perder a posição no Conselho, para servir no Executivo. De fato, o Conselho era recrutado basicamente dentro do Senado e, dessa forma, "comunicavam-se os poderes entre si, nessa espécie de cúpula política do sistema imperial" (Lopes, 2010, p. 144). Ademais, muitas das relações familiares que existiam no Senado acabaram por transferir-se para o Conselho, "onde se sucederam pais e filhos, irmãos, sogros, genros e sobrinhos" (Lopes, 2010, p. 144).

A segunda diferença residia no fato de que a Suprema Corte norte-americana estava - e ainda está - prevista no texto da Constituição de 1787, embora sua organização, jurisdição e funcionamento pudessem - e ainda possam - ser definidos por lei ordinária, ao passo que o Conselho de Estado do Brasil-Império foi retirado do texto constitucional do Império pelo Ato Adicional de 1834, voltando a existir apenas com previsão na legislação ordinária (na Lei no 234 , de 1841), embora suas opiniões fossem emitidas, muitas vezes, em assuntos materialmente constitucionais, como nos conflitos de atribuição entre os poderes constitucionais (Lopes, 2010, p. 148-149). Em terceiro lugar, é bem de ver que o Conselho de Estado possuía caráter consultivo e não deliberativo ${ }^{16}$ - en-

16 "O papel eminentemente consultivo (não deliberativo) do Conselho foi afirmado em 1850 logo após a promulgação da Lei de 4 de setembro, conhecida como Lei Eusébio de Queirós, pela qual se pôs termo 
tendimento jamais ultrapassado na mentalidade da época -, enquanto aquela Suprema Corte decidia - como ainda decide - com caráter vinculante e de precedente obrigatório para todos os demais juízes e tribunais federais dos Estados Unidos da América (Lopes, 2010, p. 149). A respeito do caráter consultivo do Conselho de Estado, colaciona-se a lição de José Reinaldo de Lima Lopes:

O Conselho opinava e para dar execução a suas opiniões dependia em primeiro lugar de confirmação do Imperador (a Resolução da consulta propriamente dita), em seguida de um ato administrativo do Ministro (Aviso, para casos singulares, Decreto ou Regulamento para instruções de caráter geral), de atos da Assembleia Geral ou atividade judicial. (2010, p. 149, grifos no original)

O Conselho de Estado brasileiro e o Poder Moderador foram, enfim, extintos pelos republicanos em 1889. Tem início no Brasil uma nova época constitucional, em que as influências deslocam-se da "Europa para os Estados Unidos, das Constituições francesas para a Constituição norte-americana" (Bonavides, 2010, p. 364). O insucesso do regime de dualidade de jurisdição do Império decorreu, em grande medida, da vexatória superioridade atribuída à autoridade administrativa em detrimento da autoridade judiciária (Aragão, 1955, p. 16), bem como do fato de ele ter se estratificado nos dispositivos do Regulamento no 124, de 1842, "não se renovando mediante organização compatível com as exigências progressivas do exercício ou função jurisdicional da administração" (Aragão, 1955, p. 20).

Apesar do seu papel tão ativo na administração do Império, de sua relevância na consolidação do direito brasileiro, notadamente do Direito Administrativo, o Conselho de Estado temeu ampliar demasiadamente as liberdades, o controle sobre o governo, a participação cidadã e outros valores (Lopes, 2010, p. 346). O ideal dos conselheiros - pelo menos da maioria deles - era liberal e constitucional, no entanto, não foi capaz de se impor de forma abstrata, nem tampouco de superar as estruturas de uma sociedade que não possuía "uma burguesia com uma dinâmica endógena que a torne a 'classe universal' de seu tempo na sociedade brasileira" (Lopes, 2010, p. 351-352).

ao tráfico de escravos, da qual houve menção no primeiro capítulo. A lei transformou o crime em pirataria e submeteu o respectivo processo de presas ao Auditor da Marinha. Esse juízo especial julgaria as presas, decidiria sobre a liberdade dos negros encontrados nos navios. A lei, no art. $8^{\circ}$, determinava que os casos seriam julgados em primeira instância na Auditoria da Marinha e em segunda instância pelo Conselho de Estado. 0 Imperador consultou o Conselho sobre o assunto. A Seção de Justiça pronunciou-se em 28 de outubro de 1850. Por maioria, decidiu que a lei não transformara o Conselho em tribunal de segunda instância. $O$ voto condutor da consulta foi de Carneiro de Leão, tendo também participado da sessão Lopes Gama e Limpo de Abreu.

[...]

O Ministro da época (o próprio Eusébio de Queirós) ou, quem sabe, o Imperador pessoalmente não se satisfez com a resposta, e, provavelmente tendo em vista a magnitude do problema político da escravidão e do fim do tráfico, remeteu o assunto ao Conselho pleno. Ali as opiniões se dividiram na sessão de 14 de novembro de 1850. Lopes Gama, Holanda Cavalcanti, Araújo Viana, Alves Branco, Carneiro de Leão, Limpo de Abreu e Lima e Silva (7 conselheiros) adotaram a mesma solução que a Seção de Justiça. Ou seja, os três conselheiros da Seção de Justiça ganharam os votos de Holanda Cavalcanti, Araújo Viana, Alves Branco e Lima e Silva." (Lopes, 2010, p. 206-208) 


\section{CONCLUSÃO}

De fato, o que hoje se conhece por Direito Administrativo adveio da França. Os princípios que constituem o alicerce desse ramo do direito, incorporados posteriormente ao direito de inúmeros outros países, foram construídos, sobretudo, a partir da jurisprudência do Conseil d'État, órgão instituído no período do denominado Consulado francês, pelo art. 52 da Constituição de 22 Frimário do Ano VIIII (13 de dezembro de 1799), à imagem do antigo Conselho do Rei, para exercer competência consultiva e, após o ano de 1806, também o julgamento dos litígios entre a Administração e os administrados. A jurisdição administrativa ou contencioso administrativo, isto é, a separação entre duas ordens de jurisdição: a administrativa e a comum, nasceu na França, não em razão de uma imposição lógico-jurídica, mas a partir de um conjunto de circunstâncias históricas desse país, especialmente da interpretação que foi conferida pelos constituintes franceses pós-revolucionários ao princípio da separação de poderes, aliada à desconfiança em relação aos juízes do Ancien Régime.

O Direito Administrativo brasileiro, tal como sucedeu em diversos outros países, sofreu forte influência do direito francês, sobretudo no tempo do Império. Nesse período, foi instituído o Conselho de Estado brasileiro pela Lei no 234, de 1841, e que durou até a Proclamação da República em 1889, isto é, vigeu no Brasil o regime de dualidade de jurisdição que, porém, não funcionou de maneira sistematizada. O Conselho de Estado do Brasil-Império - não o da Constituição de 1824 que restou abolido pelo Ato Adicional de 1834, mas aquele que foi constituído pela Lei no 234, de 1841 - era o órgão de consulta do Poder Moderador, a quem cabia exercer atribuições de orientação governamental e administrativa. Cabia-Ihe, ainda, pronunciar-se sobre os conflitos de atribuição entre as autoridades administrativas e de jurisdição entre estas e o Judiciário, bem como sobre os litígios entre a Administração e os particulares, não obstante seus pronunciamentos tivessem caráter meramente consultivo e não deliberativo - as opiniões do Conselho dependiam de confirmação do imperador -, entendimento que acabou prevalecendo entre os juristas da época e no âmbito do próprio Conselho.

À guisa de conclusão, entendemos que o sistema de dualidade da jurisdição, notadamente quando estruturado em tribunais administrativos autônomos, proporciona algumas vantagens tanto para o Poder Público como para o cidadão. De fato, o sistema em questão não sobreviveu na França e em outros países europeus, tais como Alemanha, Áustria e Portugal apenas por força de uma tradição. O Direito Administrativo apresenta certas peculiaridades (v.g. questões que envolvem discricionariedade político-administrativa) que exigem especialização e uma forte dose de equilíbrio dos corpos da magistratura. A nosso ver, o sistema de dualidade de jurisdição tende a promover a especialização teórica e prática dos juízes que, por conseguinte, passam a conhecer, mais detidamente, os desafios e os problemas típicos da Administração Pública. A especialização 
dos tribunais, por outro lado, contribui para o incremento da legitimidade em matéria de controle de políticas públicas, evitando-se o ativismo judicial exacerbado ou a autocontenção excessivamente deferente.

Por outro lado, a importação de um sistema europeu, com o qual o Brasil não teve mais contato desde a proclamação da República em 1889, não nos parece viável, nem tampouco panaceia para todos os males da Administração Pública brasileira. Esta, ainda que seja uma das vítimas da recente crise financeira global, possui problemas, necessidades e desafios distintos da maioria dos países europeus. De fato, o Poder Judiciário brasileiro tem desempenhado, desde a redemocratização, um papel extremamente relevante na concretização da Constituição - ainda que muitas de suas decisões possam ser objetos de crítica -, funcionando no imaginário popular, como a ultima ratio na tutela dos direitos fundamentais. É necessário, contudo, aperfeiçoar o sistema de unidade da jurisdição no Brasil, dotá-lo de racionalidade, pois não nos parece razoável, por exemplo, que uma decisão proferida pelo Tribunal de Contas da União - que nos casos de imputação de débito ou multa têm eficácia de título executivo (art. 71, § 3o, da Constituição de 1988) -, cujos Ministros possuem as mesmas garantias, prerrogativas, impedimentos, vencimentos e vantagens dos Ministros do Superior Tribunal de Justiça, possa ser anulada por outra proferida pela Justiça Federal de primeira instância.

Finalmente, o estudo do contencioso administrativo na Europa, bem como do Conselho de Estado do Brasil-Império é, a nosso juízo, extremamente importante para compreendermos, de maneira crítica, as raízes teóricas e históricas e a própria evolução do Direito Administrativo brasileiro. Apesar do malogro do contencioso administrativo brasileiro, é importante reconhecer o relevante papel desempenhado pelo Conselho de Estado na orientação governamental e administrativa do Império, bem como sua relevância na consolidação do Direito brasileiro, notadamente do Direito Administrativo, ainda que o Conselho não tenha sido capaz de superar as estruturas de uma sociedade dependente da escravidão e dos grandes proprietários rurais.

\section{REFERÊNCIAS}

ALESSI, Renato. Instituciones de derecho administrativo. Trad. de Buenaventura Pellisé Prats. Barcelona: Bosch, t. II, 1970.

ARAGÃO, J. Guilherme de. A justiça administrativa no Brasil. Cadernos de Administração Pública, Fundação Getúlio Vargas, Rio de Janeiro, n. 25, 1955.

BARROSO, Luís Roberto. O direito constitucional e a efetividade de suas normas: limites e possibilidades da Constituição brasileira. 5. ed. Rio de Janeiro: Renovar, 2001.

BONAVIDES, Paulo. Curso de direito constitucional. 25. ed. São Paulo: Malheiros, 2010.

CAVALCANTI, Themistocles Brandão. Princípios gerais de direito administrativo. Rio de Janeiro: Freitas Bastos, 1945. 
CERQUEIRA, Marcello. A constituição na história: origem e reforma: da Revolução inglesa de 1640 à crise do Leste Europeu. 2. ed. Rio de Janeiro: Revan, 2006.

CINTRA, Antonio Carlos de Araujo, et al. Teoria geral do processo. 25. ed. São Paulo: Malheiros, 2009.

CRETELLA JÚNIOR, José. Droit administratif comparé. São Paulo: Bushatsky, Ed. da Universidade de São Paulo, 1973.

Tratado de direito administrativo. São Paulo: Forense, v. I, 1966.

DI PIETRO, Maria Sylvia Zanella. 500 Anos de direito administrativo brasileiro.

Revista Diálogo Jurídico, Salvador, CAJ - Centro de Atualização Jurídica, n. 10, janeiro/2002. Disponível em: <http://www.direitopublico.com.br>.

Acesso em: 17 dez. 2012.

. Direito administrativo. 23. ed. São Paulo: Atlas, 2010.

FAUSTO, Boris. História do Brasil. 14. ed. São Paulo: Ed. da Universidade de São Paulo, 2012.

FRANCO, Afonso Arinos de Melo. Estudos de direito constitucional. Rio de Janeiro: Forense, 1957.

HOBSBAWN, Eric J. A era das revoluções. Trad. de Maria Tereza Teixeira e Marcos Penchel. 25. ed. São Paulo: Paz e Terra, 2010.

KELSEN, Hans. Teoria geral do direito e do estado. Trad. de Luís Carlos Borges. 3. ed. São Paulo: Martins Fontes, 1998.

LOPES, José Reinaldo de Lima. O oráculo de Delfos: Conselho de Estado e direito no Brasil oitocentista. São Paulo: Saraiva, 2010.

MAGALHÃES JÚNIOR, R. Três panfletários do segundo reinado. Rio de Janeiro: Academia Brasileira de Letras, 2009.

MELLO, Celso Antonio Bandeira de. Curso de direito administrativo. 27. ed. São Paulo: Malheiros, 2010.

MONTESQUIEU, Charles-Louis de. O espírito das leis. Trad. de Cristina Murachco. São Paulo: Martins Fontes, 2000.

MOREIRA NETO, Diogo de Figueiredo. Contencioso administrativo. Rio de Janeiro: Forense, 1977.

RIVERO, Jean. Direito administrativo. Trad. de Rogério Ehrhardt Soares. Coimbra: Almedina, 1981.

SCHMITT, Carl. O guardião da constituição. Trad. de Geraldo de Carvalho. Belo Horizonte: Del Rey, 2007.

URUGUAY, Visconde do. Ensaio sobre o direito administrativo. Rio de Janeiro: Typographia Nacional, t. I, 1862.

VARELA, Alfredo. Direito constitucional brazileiro: reforma das instituições nacionaes. 2. ed. Rio de Janeiro: Livraria H. Garnier, 1902.

WEHLING, ARNO. Verbete Montesquieu. In: BARRETO, Vicente de Paulo (Coord.). Dicionário de filosofia do direito. São Leopoldo: Unisinos; Rio de Janeiro: Renovar, 2009. 